\title{
Wheat blast disease: Bangladesh and global perspectives of blast resistance
}

\section{Thoihidul Islam, Mohammad Rashid Arif, Lutful Hassan and ${ }^{\otimes}$ Arif Hasan Khan Robin}

Department of Genetics and Plant Breeding, Bangladesh Agricultural University, Mymensingh 02202, Bangladesh

\begin{tabular}{l} 
ARTICLE INFO OPENCAccess \\
\hline Article history: \\
Received : 26 December 2018 \\
Accepted : 01 April 2019 \\
Published: 30 June 2019
\end{tabular}

Keywords:

Wheat blast, Magnaporthe oryzae, resistance, molecular markers, research collaboration

Correspondence:

Arif Hasan Khan Robin

凹: gpb21bau@bau.edu.bd

\begin{abstract}
Fearsome wheat blast disease expanded its radius from Latin America to Bangladesh in 2016 with higher degrees of destruction efficiency. In 1985, Brazil was the first hotspot and consecutively Paraguay, Argentina, Bolivia were affected by the wheat blast fungus. Blast fungus Magnaporthe oryzae is under pyriculariaceae family with three-celled, pyriform, hyaline conidia. Not only wheat and rice are affected by the blast pathogen but also around 50 grass species can be affected and act as host, but the fungus pathotype is specific and distinct for each plant species. Morpho-biometrical analysis revealed similarity between the Magnaporthe oryzae pathotype Tritici (MoT) strain of Bangladeshi and Brazil. Through extensive molecular genetics and genomics study unfolded five resistant genes, among those Rmg2, Rmg3, and $R m g 7$ lost viability but $R m g 8$ and $R m g G R 119$ still have resistance. In addition, 2NS translocation from Aegilops ventricosa in wheat reports resistance against MoT. CIMMYT based Milan variety is regarded as a resistant variety and plant breeders are trying to develop new resistant varieties. But the main problem regarding blast pathogen is breakdown of resistance and evolving virulent races consecutively which is fueled by global warming. A wide range of molecular markers can potentially be used for blast resistance study. Utilization of medium to high-throughput markers like SSR, InDel and SNP gave pace in blast resistance study. Along with that, allele mining has potentiality for finding out source of resistance. In addition, gene pyramiding will play a vital role in introgression of multiple resistant genes into a superior wheat linage. In future, high-throughput marker technology along with cutting-edge gene editing technology will play a pivotal role. Furthermore, the collaborative research in Bangladesh indicates that international scientific community has taken wheat blast as a serious issue.
\end{abstract}

\section{Introduction}

From the beginning of agricultural revolution, some terrifying crop diseases appeared in our planet as epidemic that resulted in catastrophe like famine. As for example, the great Irish famine in 1845 late blight disease outbroken in potato where about one million Irish folks died of starvation that estimated approximately $12 \%$ of the total population and eventually 1.9 million European people migrated to America as refugee for their survival (Encyclopedia Britannica, 1999). Then Bengal famine in 1943 due to Brown spot disease outbreak in rice caused $40-90 \%$ yield reduction and that resulted in death of about two million people by starvation (Gunnell, 1992; Padmanabhan et al., 1973).

In last few decades the intensity of fungal diseases has increased gradually (Fisher et al., 2012). Blast disease is a fungal disease, for which scientists have become concerned and dwelling on to confront it for the sake of mankind. In Latin, blast is called as "Brusone". Fungus named Magnaporthe oryzae (syn. Pyricularia oryzae) under pyriculariaceae family is the causal organism of blast disease (Couch and Kohn, 2002). Blast disease has a devastating influence on the yield and production of rice (Skamnioti and Gurr, 2009). Likewise, in wheat the destruction efficiency of this fungus is beyond word because the crop loss was between 40 and $100 \%$ in Latin America (Kohli et al., 2011; Goulart and Paiva, 1990).

Blast is a disease of major cereal belonging to poaceae family members. Rice is the staple food for more than half of the population of the world (Skamnioti and Gurr, 2009). In contrast, wheat is providing $20 \%$ calories and protein worldwide and especially $50 \%$ in developing countries (CSISA, 2014). Around 531 calories person $^{-1}$ day $^{-1}$ was supplied by wheat in the year of 2005 (FAOSTAT, 2010). As it is a disease of principal cereal crops such as rice and wheat, therefore it can demolish the food security of millions of inhabitants of this globe (Fisher et al., 2012; Pennisi, 2010; Liu et al., 2014). In addition to rice and wheat 50 grass species may be affected by this pathogen (Ou, 1985). High degree of host selectivity is present in $M$. oryzae species. (Klaubauf et al., 2014; Kato et al., 2001). M. oryzae from rice is genetically distinct from isolates infecting wheat (Urashima et al., 1993; Prabhu et al., 1992; Urashima et al., 1999; Farman, 2002; Faivre-Rampant et al., 2008; Tufan et al., 2009; Maciel et al., 2014; Chiapello et al., 2015; Yoshida et al., 2016). Blast fungus has been classified into some pathotypes according to its crop-specificity, viz., rice (Oryza

\section{Cite this article}

Islam, M.T., Arif, M.R., Hassan, L. and Robin, A.H.K. 2019. Wheat blast disease: Bangladesh and global perspectives of blast resistance. Journal of Bangladesh Agricultural University, 17(2): 122-132. https://doi.org/10.3329/jbau.v17i2.41934 
pathotype), wheat (Triticum pathotype), ryegrass (Lolium pathotype), foxtail millet (Setaria pathotype) and so on (CIMMYT, 2016).

Wheat blast primarily attack on spikes; the affected spikes become bleached and that results either deformed seed or no seed development. This disease may attack the highly susceptible line at the seedling stage under inoculated condition (USDA, 2013). The highly affected wheat head can be dead and as a result, drastic yield reduction may happen. So the most common identifiable symptom is bleaching of spikelets and entire head at the premature stage (Igarashi, 1990; Urashima et al., 2010; Malaker et al., 2016).

Blast fungus is an ascomycete fungus which has pyriform macro-conidia with an approximate size of 20 $\times 10 \mu \mathrm{m}$. Macro-conidia are generated on conidiophore. In a favorable environment, macro-conidia germinate and appressorium is produced which remains at the apex of the germ tube. Further, an infection peg initiates and enter into the plant tissues. The appressorium is bowlshaped and melanin is present in the wall of appressorium (Kato, 2001). The three-celled pyriform conidia get attached tightly to plant surface using spore beak mucilage which is produced by conidium hydration (Howard and Valent, 1996). Ascospores and microconidia are also formed in case of sexual reproduction. Although sexual reproduction has not been observed in nature but some strains follow sexual reproduction in controlled condition (Yaegashi and Udagawa, 1978). The sexually fertile blast isolates of wheat are capable of producing functional ascospores in suitable condition. Ascospores are generated in unordered asci and 'perithecia' named fruiting body bears the asci (Urashima et al., 1993). The fertile isolate also produces sickle-shaped, minute micro-conidia having the length of 6.0 micrometers and the breadth of 0.7 micrometers. From phialides, the micro-conidia are produced and under favorable conditions conidia germinate (Chuma et al., 2009). Due to polycyclic in nature, blast fungus is capable of producing spore repeatedly within seven days under wet and hot weather (Boddy, 2016). The whole genome sequence revealed that this filamentous fungus has 7 chromosomes with $40.3 \mathrm{Mb}$ genome size bearing 11,109 protein encoding genes (Dean et al., 2005).

For the outbreak of blast disease the environmental condition is one of the key factors. Accurate weather condition which triggers the epidemic is not clear, but most of the blast epidemic happened in wet weather. It is observed that continuous rainy days with a mean temperature between $18-25^{\circ} \mathrm{C}$ during the flowering stage, accompanied by hot, humid, sunny weather is responsible for blast epidemic (Kohli et al., 2011). In controlled condition, at $30^{\circ} \mathrm{C}$ the potency of blast disease rises and that is enhanced by a prolonged wetting period. A $25^{\circ} \mathrm{C}$ with lower wetting period lesser than 10 hours dwindled the intensity of blast disease. By contrast, $25^{\circ} \mathrm{C}$ temperature accompanied by 40 hours of wetting increased the disease potency which exceeded $85 \%$ (Cardoso et al., 2008). Global warming is one of the significant reasons for dissemination and development of blast disease (Kholi et al., 2011).

Dispersal of blast fungus may be occurred by seed (Goulart and Paiva, 1990). But the role of seed in epidemic development is very trivial because airborne conidia from various alternative host infect the spike of wheat (Prabhu et al.1992; Urashima et al., 1993). Certain grass weeds (Eleusine indica, Echinocloa crusgalli, Brachiaria plantaginea, Cenchrus echinatus, Pennisetum setosum, Rhynchelytrum roseum, Hyparrhenia rufa, Digitaria sanguinalis) are alternative host of Pyricularia but their role in epidemiology are not presumed properly (Prabhu et al., 1992). Considering these facts the present review was attempted to overview the perspectives of wheat blast resistance status globally and future prospects of utilizing molecular marker technology and genomics to combat this disease.

\section{Reports of blast disease}

In 1985 blast of wheat was first identified in Brazil, Parana province was the hotspot (Igarashi et al., 1986). In 1996, first epidemic occurred in Bolivia (Barea and Toledo, 1996). Consecutively, Paraguay and Argentina were attacked by wheat blast disease and resulted in 70$80 \%$ loss of total production (Alberione et al., 2008; Viedma and Morel, 2002). Due to the potency of Magnaporthe oryzae pathotype Triticum (MoT), some part of Latin America abstained themselves from cultivating wheat (Callaway, 2016). In 2011, a blast affected spikelet was found in an experimental field of USA possibly due to host jump in the wheat spikelet (Callaway, 2016).

In February 2016, wheat blast disease was reported in Asia for the very first time. Local authorities and the media reported about massive outbreak of wheat blast in Bangladesh (Callaway, 2016). The disease symptom of wheat blast was first noticed in Chuadanga and Meherpur district in mid-February in Bangladesh. This terrifying disease spread to the adjoining four districts within two weeks and in addition a coastal district named Bhola, far apart of those four districts, was reported to be affected by wheat blast (The Prothom Alo, 2016; Islam et al., 2016). Due to wheat blast epidemic, around 15000 ha land was affected which is almost 3.5\% of total wheat coverage in Bangladesh and that incidence dwindled total wheat production by $15 \%$ in 9 districts (Islam et al., 2016; Malaker et al.,2016; The Daily Star, 2016a). Plant pathologists of Wheat Research Centre (WRC) of Bangladesh Agriculture Research Institute (BARI) have predicted that there is a risk of spreading this disease in China, India, and Pakistan whilst those countries occupied the position of second, third and seventh position, respectively in wheat production (Islam et al., 2016; Index Mundi, 2016).

The current wheat production trend can cope with the demand up to 2020 and in 2050 the yield gap will be 
around one ton $\mathrm{ha}^{-1}$. Along with the yield gap, evolving new pathogen race, pest, and climatic instability will increase the risk of reduced food production and tends to food insecurity. Various studies are supporting this phenomenon and evolving new virulent strains of Phytophthora infestans, Puccinia striiformis and $P$. graminis are the evident examples (Fig. 1, Mondal et al., 2016; Garrett et al., 2006; Hovmoller et al., 2008; Singh et al., 2011; Cooke et al., 2012; Bebber et al., 2013). So, it is urgent to develop new wheat varieties with durable blast resistance.

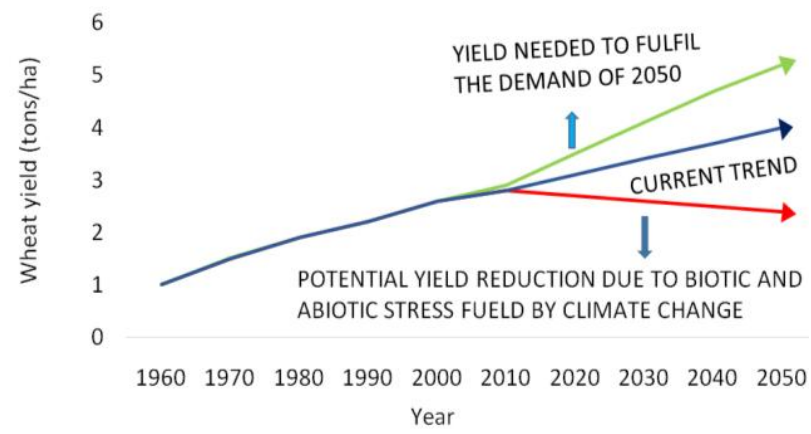

Fig. 1. Overall scenario of global wheat production trend (Redrawn from Global Rust, 2016)

\section{Resistance research for blast disease}

After first blast outbreak in 1985 in Brazil, scientists started searching for sources of resistance for confronting this terrifying disease but the way was much harder than the scientists thought (Urashima et al., 2004; Prestes, 2007; Cruz et al., 2010, 2016). Previous studies concluded that, the genetic basis of resistance is not well defined for large-scale variation in virulence within blast fungus (Urashima et al., 2004). Some Brazilian cultivar like IPR 85 and CD 113 and BR 18 showed the moderate level of resistance against blast, while Bolivian cultivar named Paragua CIAT and Parapeti CIAT showed a comparatively higher level of resistance. But cultivar named Milan derived from CIMMYT (International Maize and Wheat Improvement Center) line showed the highest level of resistance (Kholi et al., 2011).

The resistance against blast pathogen so far made is based upon $\mathrm{R}$ gene. The main problem based on $\mathrm{R}$ gene resistance is "breakdown of resistance" due to the high level of pathogenic variance within blast pathogen (Kiyosawa, 1982; Leach et al., 2001). Genetic studies showed that wheat blast pathogen (Magnaporthe oryzae Tritici) postdate a gene-for-gene relationship alike rice blast patho-system (Silué et al., 1992; Anh et al., 2015). Though dozens of $\mathrm{R}$ genes have been identified for rice blast but in wheat, the range of identified $\mathrm{R}$ genes is very narrow (Liu et al., 2014; Cruz et al., 2016). But few R genes have been identified by scientists. "Rmgl" (Rwt 4) is responsive against Avena isolate but not for Triticum isolates (Takabayashi et al., 2002). Then "Rmg4", "Rmg5" showed resistance to Digitaria isolate but not against Triticum isolate (Nga et al., 2009). "Rmg6" was ineffective against Triticum isolate but responsive against Lolium isolate (Vy et al., 2014). Thus, it is evident that these four genes are inappropriate for resistance against wheat blast disease. But in opposite direction four $\mathrm{R}$ genes have been identified which are responsive against Triticum isolate. "Rmg2", "Rmg3" were identified from a common wheat variety named Thatcher (Zhan et al., 2007) and previously these two R genes showed resistance in seedling stage but a later study revealed, these two resistance genes lost the resistance status (Anh et al., 2015). Afterwards, Rmg7 was identified from tetraploid Triticum dicoccum but the astute MoT strain has overcome the R gene (Cruz and Valent, 2017). Another $\mathrm{R}$ gene has been identified named as "Rmg8", derived from hexaploid wheat. This "Rmg8" gene is a dominant gene showing high resistance against Triticum isolate $\mathrm{Br} 48$ and occupying the long arm of 2B chromosome (Anh et al., 2015). Along with Rmg8, Wang et al. (2018) found another wheat blast resistance gene in a local landrace GR119 that gene was designated as RmgGRI19. In GRI19 the cumulative effect of $R m g 8$ and $R m g G R 119$ gave a strong blast resistance status (Wang et al., 2018).

During studying wheat head resistance trait Cruz et al (2016) have found a wild chromosome segment (2NS translocated from Aegilops ventricosa). In 2014 and 2015, it was tested in Bolivia and scientists concluded that this 2NS chromosome segment is resistant against wheat head blast (Cruz et al., 2016). CIMMYT based variety Milan containing 2NS segment showed resistance against wheat blast (Cruz et al., 2016). Thus, the contemporary resistance research in wheat blast is Rmg8, RmgGR119 gene and 2NS translocation based. From the previous study, it is distinct that "breakdown of resistance" may occur of this resistance genes or segment and new virulent pathogen may evolve. In 2016, epidemic happened in Bangladesh and this $M o T$ strain was more virulent than before (CIMMYT, 2016). So, searching for new resistance gene in unexamined genotypes, landraces, weediforms and close related species is an urgent need. Plant scientists have to do this before the evolution of this deadly fungus, otherwise, the world will face a catastrophe.

\section{Molecular genomics and genetics for blast disease resistance}

Studying molecular genomics and genetics explicitly in wheat is the prerequisite for developing blast diseaseresistant durable cultivar. QTL identification, QTL mapping, gene pyramiding, Allele mining for Marker assisted selection (MAS), Marker-assisted backcrossing (MABC) using molecular markers and relevant biotechnological approaches are the probable approaches for confronting wheat blast.

Considering the interaction between resistance gene(s) and pathogen reproduction, blast resistance can be stratified into two categories, one is complete resistance and another is partial resistance. Though complete resistance is monogenic (not durable in general), single 
$\mathrm{R}$ gene is responsible for resistance and complete resistance is coined as qualitative resistance. Complete resistance occurs due to the incompatibility between fungus strain and host, as a result, reproduction of fungus restricted (Wang et al., 1994). In rice, Ashkani et al. (2015a) successfully characterized and cloned 22 rice $\mathrm{R}$ genes which refer to complete resistance. But the lower durability is the main shortcoming of the monogenic $\mathrm{R}$ gene based resistance (Cruz and Valent, 2017). In another direction, partial resistance is a quantitative attribute and non-race specific controlled by many minor genes and every minor genes cumulative effect results in resistance. Quantitative Resistance Loci (QRL) controlled the partial resistance and in partial resistance, the pathogen reproduction is dwindled due to a limited interaction between host and pathogen (Wang et al., 1994; Young, 1996). In rice, the breakdown of resistance occurs after a few years due to $M$. oryzae overcome the virulence and quantitative resistant loci can be a possible source for durable resistance against the blast pathogen and previously QRL detection was used for identifying resistant genes against blast (Song and Goodman, 2001;Wang et al., 1994; Fukuoka and Okuno, 2001 ; Miyamoto et al.,2001; Tabien et al.,2002; Zenbayashi et al.,2002; Chen et al., 2003; Sallaud et al., 2003; Talukder et al., 2004; Wu et al., 2005; Ashkani et al., 2013a,b). So, for tackling blast epidemic for a short period, monogenic $\mathrm{R}$ gene is one of the probable options which can confront blast disease. In contrary, for durable resistance introgression of Quantitative Resistance Loci (QRL) will play a vital role in the blast resistance breeding program. Moreover, if a cultivar contains both monogenic and polygenic resistance the durability, stability will be far better compared to any resistant cultivar but in practice that would be challenging.

Allele mining is one of the potential ways of identifying blast resistant genes. Allele mining used for identifying a target allele of gene using the broad information related that specific gene from a broad spectrum germplasm and this technique has the higher potentiality for crop improvement (Ashkani et al., 2015a). Generally, local landraces and wild relatives are the sources of useful alleles (Tanksley and Nelson, 1996). Commonly two approaches are being used for extensive allele mining one is EcoTilling and another is sequence based allele mining. EcoTillering is comparatively easier and costeffective than sequence-based allele mining (Kumar et al., 2010; Ashkani et al., 2015b). Allele mining consists of identification of allele, allelic variation identification, characterization of allelic variation, and identification of haplotype, studying haplotype diversity, evolutionary relationship study, and analysis of similarity and development of molecular markers for identifying and differentiate a specific allele from one another (Ashkani et al., 2015b). So identifying resistant allele by using allele mining is a distinct way of getting resistance from unexamined varieties, landraces, and wild cultivar.
Furthermore, gene pyramiding is another distinct way of getting sustainable resistance against blast. Gene pyramiding is cumulating genes in a single line. Various genes are identified in different parents then accumulated into a single genotype. Gene pyramiding technique is broadly used in developing disease and pest resistance durable cultivar (Ashkani et al., 2015a). For instance, many $\mathrm{R}$ genes refer resistance against blast pathogen but could not withstand due to break down of resistance. If all the $\mathrm{R}$ genes are introduced in the same genotype, the resistance will be far better than a single $\mathrm{R}$ gene controlled genotype and it will give a sustainable solution. In rice blast disease, gene pyramiding considered as one of the best ways for getting longlasting resistant cultivar (Koide et al., 2010). This gene pyramiding can be accelerated by using marker-assisted selection where the molecular markers are commonly used for identifying the desired alleles and recombining all genes properly into a single genotype (Joshi and Nayak, 2010). Finally, it can be stated that identification of QTLs, allele mining and gene pyramiding are the sequential activities to develop genotypes with blast resistance. Developing and utilization of molecular markers is the useful way of screening, identification, and characterization of blast resistant gene.

\section{Potential application of molecular and biotechnological tools for blast disease resistance variety}

For improving disease resistance in crop, current agricultural system follows three fundamental principles. The first approach is improving cultural practice for crop production. The second approach is using conventional breeding or marker-assisted breeding for developing disease resistance cultivar and the third approach is the direct insertion of resistance gene into a superior cultivar, it can be also coined as 'genetic modification' of a crop (Baulcombe, 2004). Marker assisted selection has a potentiality for screening and developing resistant cultivar. Some other biotechnological tools utilize specialized promoters where modification of target protein structure is the key for transgenes' performance (Helliwell et al., 2013). Agrobacterium-mediated gene transfer makes transferring a target transgene possible in wide range of species and use of different promoters can regulate the expression of a genes related to resistance (Baulcombe, 2004).

To date, molecular markers have opened a new era in case of molecular plant breeding. In rice breeding, molecular markers played an immense role in identifying, improvement, selection and germplasm collections (Wang et al., 2007). Additionally, many researchers reviewed the usefulness of molecular markers in rice breeding (Temnykh et al., 2001; Semagn et al., 2006; Lang et al., 2008; Kumar et al., 2009). So, it can be inferred that molecular markers can be utilized in wheat breeding and specifically for blast resistance. New biotechnological tools have been given a new pace in molecular biology including resistance study. In the $21^{\text {st }}$ 
century, new techniques have been discovered which giving scientists' new hope. The technology termed as genome editing (GE) technology can distinctly modify or repair even a single nucleotide. The CRISPR/Cas9 is the most promising GE technique, released in 2012 that is based on defense mechanism of bacteria against the virus (Gasiunas et al., 2012; Jinek et al., 2012; Cong et al., 2013). Recently a rice blast resistant line has been released using CRISPR/Cas9 and this is the new hope for the plant breeders (Wang et al., 2016). Notably, the success of CRISPR/Cas9 in rice is higher compared to wheat, because of genome flexibility of rice compared to genome complexity in wheat. In wheat, till now regeneration from genome edited protoplast was not possible. The scientists of Chinese Academy of Sciences obtained the first CRISPR/Cas9 edited wheat plant that has emerged as a new hope (Wang et al., 2014).

In contrast to CRISPR/Cas9, Target Induced Localized Lesion in Genome (TILLING) is also a good alternative not only because the mutagenized plant can be grown in field condition but also the wheat hexaploid genome has high sustainability against mutation (Chen et al., 2012). TILLING is a reverse genetic approach discovered in 2000 which is based on point mutation (Greene et al., 2003). Like other genome-editing techniques transcription activator-like effector nuclease (TALEN) is one of the potential approaches. TALEN has been successfully deployed to develop blast resistant rice plant (Malzahn et al., 2017; Li et al., 2012). So, it can be expected that the modern GE technique will play a crucial role in blast resistance study as well as in the sphere of molecular biology with a new dimension.

\section{Molecular markers and blast resistance study}

After discovery, the marker technology is assisting plant breeders to identify the changes in DNA level. In major crop species, a large number of a disease-resistant trait is directly linked with various molecular markers, markers are being used extensively to find out loci and targeted genomic region in breeding programs (Phillips and Vasil 2001; Jain et al.,2002; Gupta, 2004). Molecular markers are also being used for gene introgression using phylogenetic analysis, characterization of germplasm and backcrossing (Jain et al., 2002).

Simple Sequence Repeat (SSR) or micro-satellite markers have largely been used compared to other marker system until date. From wheat isolates, thirtyeight genomic SSR loci of MoT has been characterized and new SSR markers have been developed (Pereira $e t$ $a l ., 2014)$. SSR marker used to confirming a gene named $\operatorname{RmgTd}(\mathrm{t})$ provides mild resistance to tetraploid wheat against MoT and mapping of Rmg8 gene of hexaploid bread wheat (Anh et al., 2015; Cumagun et al.,2014). Using SSR markers many resistant genes have been unleashed in rice, like $P i-t a 2, P i-k h, P i-b, P i-z, P i-9, P$ $i 2$ and so on. Huge online database information is available in "http:// www.gramene.org" regarding SSR marker which has been developed and validated for rice blast research. SSR markers have been used successfully for gene identification, QTL mapping, pyramiding and backcrossing (Sallaud et al., 2003; Ashkani et al., 2013a,b; Singh et al., 2012; McCouch et al., 1994; Ashkani et al., 2011; Correa Victoria et al., 2001).

The discovery of InDel and SNP marker has begun a "renaissance" in the field of molecular marker technology. In rice blast resistance study, InDel marker has been developed and utilized for resistant genes like Piz, Piz-t, Pik, Pik-m, Pik, Pik-m, Pik, Pi39, Pi50(t), Pijnw1. In a rice restorer line named Hanghui 1179, resistant genes has been analyzed using InDel marker (Hayashi et al., 2006; Zhou et al., 2017).

Single Nucleotide Polymorphism (SNP) has taken the supremacy over SSR as they are unique and plentiful in high and ultra-high-throughput automation. Haplotying is capable of finding out polymorphism within a single base pair (Mammadov et al., 2012). SNP markers have been developed for blast resistant genes named Piz, Pizt, Pit, Pik, Pik-m, Pikp, Pita, Pita-2, and Pib respectively in Japan for blast resistance rice breeding program (Hayashi et al., 2004; Hayashi et al., 2006). Then, transcriptomic SNPs identified for studying MoT and this study revealed that wheat blast causing strain of Bangladesh has close similarity with Brazilian isolates. From revealed transcriptomic SNPs new SNP marker will be developed and characterization of newly evolved MoT strain will be easier (Islam et al., 2016; Fig. 2).

From the above discussion, it is noticeable that utilization of marker technology has given a pace in blast resistance research and with the elapse of time the accuracy of marker technology is increasing. So it is expected that in marker assisted selection for blast resistant wheat variety modern cutting edge markers like SNP and InDel will play a pivotal role.

\section{Bangladesh and wheat blast}

The scientists of Bangladesh Agriculture Research Institute (BARI) reported the first occurrence of the wheat blast to Government of Bangladesh (GoB) in February 2016. Then GoB alerted national, regional and international levels that wheat blast could be epidemic in South-Asia (ACIAR, 2017). Instantly the pathologists of Government organization (Go) and Non-government organizations (NGo) visited 39 spots of 8 districts and collected disease samples along with necessary information by a team consisted with members from UN Food and Agriculture Organization (FAO), Bangladesh Agricultural University, Department of Agriculture and Food, Western Australia (DAFWA) and Bangabandhu Sheikh Mujibur Rahman Agricultural University (BSMRAU). In late March 2016, GoB formed a core committee and that core committee gave future action plan to the Ministry of Agriculture (MoA) to confront the wheat blast. As an immediate action, they forbade to store any infected seeds and all infected grain must be slashed and burned. Then the core committee suggested 
for seed treatment, test for MoT, and assess the host specificity as a short-term action. As a long-term work plan, the core committee recommended identifying sources of resistance using conventional and molecular breeding approaches, finding out alternative host of MoT, generating a forecasting model for blast outbreak, assessing seed health before variety release, maintaining strict quarantine system and finally providing training and workshop to extension personnel so that as they can increase their diagnosis skill (The Daily Star, 2016b; Personal communication, Professor $\mathrm{Dr} M$ Bahadur Meah, Chairman of Core committee formed by Government of Bangladesh for immediate suggestions during wheat blast epidemic).

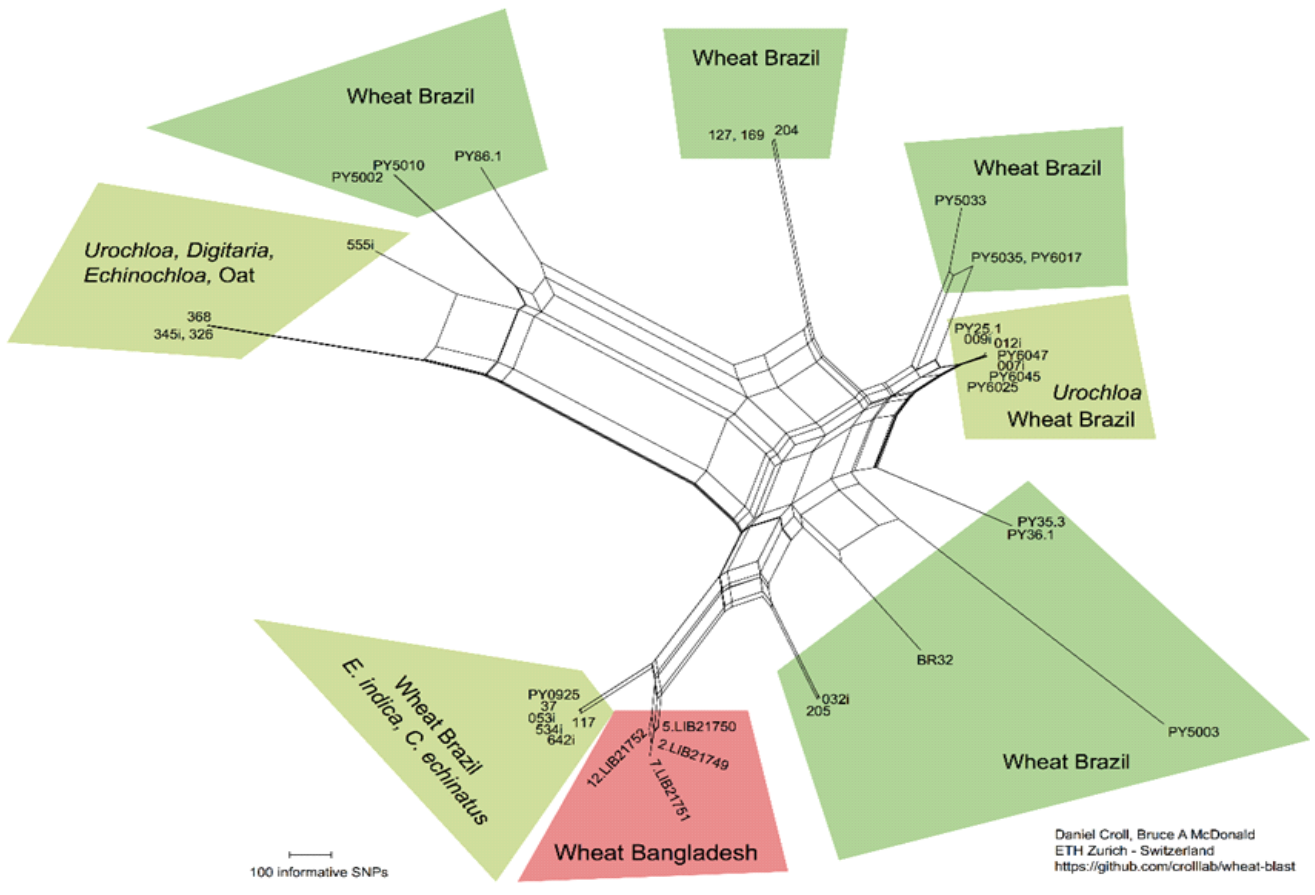

Fig. 2. Closeness of MoT from Brazilian and Bangladeshi isolates (Pathogen-genomics, 2016)

At this juncture of epidemic in 2016, BSMRAU conglomerated with The Sainsbury Laboratory and The Genome Analysis Centre (TGAC) respectively to initiate an "OpenWheatBlast" (http://s620715531.websitehome. co.uk/owb/) database where relevant information about wheat blast would be available and till date they are working on wheat blast resistance (Islam et al., 2016; The daily star, 2016a).

Now, many national and international organizations are working independently or collaboratively in Bangladesh. After the epidemic in Bangladesh in 2016, Australian Center for International Agriculture Research (ACIAR) has taken an initiative along with CIMMYT to develop durable blast resistant wheat variety (CIMMYT, 2017a). Indian Council of Agricultural Research (ICAR) granted a budget to carry out research in south Asia that will be led by CIMMYT (CIMMYT, 2017b). Additionally, United States Agency for International Development (USAID) is running projects named the Climate Services for Resilient Development (CSRD) and the Cereal Systems Initiative for South Asia (CSISA), the CGIAR Research Program on Wheat by CGIAR and the Durable Genetic Gains in Wheat (DGGW) funded by Bill \& Melinda Gates Foundation. After the wheat blast epidemic, they also paid heed to this issue (ACIAR, 2017).
For developing skilled manpower, training and workshops are being arranged in Bangladesh. In April 2017, CSISA led by CIMMYT carried out a 12 days long training aimed at surveillance and monitoring on blast. Experts from Cornell University, Kansas State University, CIMMYT, and CGIAR research program on wheat facilitated the training (CSISA, 2017). Then in February 2018, CIMMYT organized a training for young wheat researchers to provide exposure on using modern tools like artificial intelligence based disease identification using the smartphone and so on (CIMMYT, 2018).

In 2017, Wheat Research Centre (WRC) of BARI released a wheat variety named BARI Gom33 (parentage of BARI Gom33 is Kachu/Solala) is blast resistant as well as Zinc enriched (CIMMYT, 2017b; Personal communication, Dr Naresh Chandra Deb Barma, Director General, Bangladesh Wheat and Maize Research Institute). Moreover, GoB has taken the policy to discourage the farmers from wheat cultivation for a few years in the vulnerable districts and to replace wheat with alternate crops like boro rice, chickpeas, potatoes etc. (CIMMYT, 2019). So it is evident that, the international research community especially CIMMYT, ACIAR and Kansas State University (KSU) along with GoB have taken this issue seriously and their quick 
response towards the wheat blast have given a leap of hope in Bangladesh. Additionally, the collaborative research programs amongst Go and NGo have added a new dimension.

\section{Future outlook of blast resistance research}

The discussed information indicates that, in future the control of wheat blast will be one of the greatest challenges for scientists because of adverse effect due to climate change. Plant breeders will search for novel resistant genes in unexamined variety, landraces, weediforms, and closely related species and will try to identify and introgress into high yielding sustainable wheat varieties. Additionally, more 2NS translocation based wheat variety will be introduced as blast resistant variety. Mutation breeding will play a vital role in developing wheat blast resistant cultivar where seed irradiation may create variation with blast resistance. Then scientists will try to explore more protein domains like nucleotide-binding site (NBS), leucine-rich repeat (LRR), coiled coil(CC) and nucleotide-binding site leucine-rich repeat (NBS-LRR) from unexamined sources in quest of resistance. For shortening the breeding cycle quick breeding methods i.e. Rapid Growth Analysis (RGA) will be utilized. The hostpathogen interaction study will be carried out to reveal the pattern of "breakdown of resistance" and pathologists will try to dissect the ecology of Magnaporthe oryzae along with host specificity and cross infection pattern.

More high-throughput and allele specific marker like SNPs and InDels will be developed and utilized with cost-effective, quick genome studying platform, especially the next generation sequencing platforms will be replaced by modern sequencing platform and may be used in the unexamined wheat genome and as a result the marker-assisted breeding will be more dynamic. Allele mining and other in silico analysis will be accelerated due to new cutting-edge bioinformatics tools. Previous studies showed that, in eukaryotes MicroRNAs (miRNAs) have role in the defense mechanism, so identifying and utilizing miRNAs of wheat will give a pace (Katiyar-Agarwal and Jin, 2010). In addition, newly developed modern forecasting model may be a key factor in preventing blast epidemic.

Additionally, gene transfer technique will play a big role but will bring out controversy because of biosafety issue. Finally, the newly developed cutting-edge technology like TALEN, TILLING, CRISPR/Cas9 may play a vital role in developing Genetically Edited wheat resistant against wheat blast. In addition, nanotechnology will be deployed, like NANO GREEN named Nano-molecules has been used against rice blast (Srivastava et al., 2017).

Indeed these new biotechnological and bioinformatics tools are giving aspiration for confronting wheat blast as like as any other biotic stress. In future, collaborative research horizon will be more intensified and knowledge exchange and sharing will generate a big data platform for scientists.

\section{Conclusion}

The identification of blast disease and epidemic occurrence in Bangladesh has given a push to the scientific world. Additionally, the devastating effect of Magnaporthe oryzae in Brazil, Bolivia, Uruguay, and Argentina is giving urges to the plant breeders. Early works proved that MoT has higher level of virulence and pathogenicity. Then the evolving strategy of new strain is unknown and the host-pathogen interaction is complicated. In addition, the environmental change is fueling this disease. Amongst molecular markers InDel and SNPs have the most potency. The high-throughput marker technology will boost the QTL identification, mapping and gene introgression. The marker-assisted selection (MAS), marker-assisted backcrossing (MAB) will be carried out using identified QTLs and genes. Exploitation for new resistance protein domain may add new attributes. The cutting-edge technology like TALEN, TILLING and CRISPR/cas9 will bring out a paradigm shift in wheat blast research. Lastly, the exchange of information between scientists is the most important concern. In Bangladesh, the exchanges of information and collaboration between national and international organizations have reflected visible significance. With the conglomeration of this all interventions, our expectations are durable wheat blastresistant variety would be developed to save mankind from another disaster. The pivotal question is, can the scientists capable of doing that mighty novel deed or not?

\section{References}

ACIAR, 2017. Available online: https://www.aciar.gov.au/project/ CIM/2016/219/

Alberione, E., Bainotti, C., Cettour, I. and Salines, J. 2008. Evaluation of diseases in summer planting wheat in the ArgentineCampana NEA 2007/2008. Proceedings of the $7^{\text {th }}$ National Congress of Wheat, Santa Rosa, La Pampa, Argentina.

Anh, V.L., Anh, N.T., Tagle, A.G., Vy, T.T.P., Inoue, Y., Takumi, S., Chuma, I. and Tosa, Y., 2015. Rmg8, a new gene for resistance to Triticum isolates of Pyricularia oryzae in hexaploid wheat. Phytopathology, 105:1568-1572. https://doi.org/10.1094/PHYTO-02-15-0034-R

Araújo, L.G., Prabhu, A.S. and Filippi, M.C., 2002. Identification of RAPD marker linked to blast resistance gene in a somaclone of rice cultivar Araguaia. Fitopatologia Brasileira, 27:181-185. http://dx.doi.org/10.1590/S010041582002000200010

Ashkani, S., Rafii, M. Y., Rahim, H. A. and Latif, M. A., 2013a. Genetic dissection of rice blast resistance by QTL mapping approach using an F3 population. Molecular Biology Reports, 40:2503-2515. http://dx.doi.org/10.1007/s11033012-2331-3

Ashkani, S., Rafii, M. Y., Rahim, H. A. and Latif, M. A., 2013b. Mapping of the quantitative trait locus (QTL) conferring partial resistance to rice leaf blast disease. Biotechnology Letters, 35:799-810. http://dx.doi.org/10.1007/s10529-012$\underline{1130-1}$

Ashkani, S., Rafii, M.Y., Sariah, M., Siti, N.A.A., Rusli, I., Harun, A.R. and Latif, M.A., 2011. Analysis of simple sequence repeat markers linked with blast disease resistance genes in a segregating population of rice (Oryza sativa). Genetics and Molecular Research, 10:1345-1355. 
http://dx.doi.org/10.4238/vol10-3gmr1331

Ashkani, S., Rafii, M.Y., Shabanimofrad, M., Miah, G., Sahebi, M., Azizi, P., Tanweer, F.A., Akhtar, M.S. and Nasehi, A., 2015a. Molecular breeding strategy and challenges towards improvement of blast disease resistance in rice crop. Frontiers in Plant Science, 6:886. http://dx.doi.org/10.3389/fpls.2015.00886

Ashkani, S., Yusop, M. R., Shabanimofrad, M., Azadi, A., Ghasemzadeh, A., Azizi, P. and Latif, M. A., 2015b. Allele mining strategies: principles and utilization for blast resistance genes in rice (Oryza sativa L.). Current Issues of Molecular Biology, 17:57-74. http://dx.doi.org/10.21775/cimb.017.057

Barea, G. and Toledo, J. 1996. Identificacion y zonificacion de piricularia o brusone (Pyricularia oryzae) en el cultivo del trigo en el resistenci de Santa Cruz. Centro de Investigación Agrícola Tropical. Informe Técnico, Proyecto de Investigacion Trigo. Santa Cruz de la Sierra, Bolivia, pp.76-86.

Baulcombe, D., 2004. RNA silencing in plants.Nature, 431:356. http://dx.doi.org/10.1038/nature02874

Bebber, D. P., Ramotowski, M. A. and Gurr, S. J., 2013. Crop pests and pathogens move polewards in a warming world. Nature Climate Change, 3: 985. http://dx.doi.org/10.1038/nclimate1990

Boddy L. 2016. In: S. C. Watkinson, L. Boddy, N. P. Money (3 ${ }^{\text {rd }}$ Edition). The Fungi. pp. 245-292.Academic Press.

Callaway, E., 2016. Devastating wheat fungus appears in Asia for first time. Nature, 532:421-422. http://dx.doi.org/10.1038/532421a

Cardoso, C.A. de A., Reis, E.M. and Moreira, E.N., 2008 Development of a warning system for wheat blast caused by Pyricularia grisea. Summa Phytopathologica, 34:216221. http://dx.doi.org/10.1590/S0100-54052008000300002

Chen, H., Wang, S., Xing, Y., Xu, C., Hayes, P. M. and Zhang, Q., 2003. Comparative analyses of genomic locations and race specificities of loci for quantitative resistance to Pyricularia grisea in rice and barley. In the Proceedings of the National Academy of Sciences. pp. 2544-2549. https://dx.doi.org/10.1073\%2Fpnas.0437898100

Chen, L., Huang, L., Min, D., Phillips, A., Wang, S., Madgwick, P.J., Parry, M.A. and Hu, Y.G., 2012. Development and characterization of a new TILLING population of common bread wheat (Triticum aestivum L.). PloS One, 7:e41570. https://doi.org/10.1371/journal.pone.0041570

Chiapello, H., Mallet, L., Guerin, C., Aguileta, G., Amselem, J., Kroj, T., Ortega-Abboud, E., Lebrun, M.H., Henrissat, B. and Gendrault, A., 2015. Deciphering genome content and evolutionary relationships of isolates from the fungus Magnaporthe oryzae attacking different host plants. Genome Biology and Evolution, 7:2896-2912. https://doi.org/10.1093/gbe/evv187

Chuma, I., Takeshi, S., Naoki, H., Ken-ichi, I., Hitoshi, N., Pyoyun, P. and Yukio, T., 2009. Cytological characteristics of microconidia of Magnaporthe oryzae. Journal of General Plant Pathology, 75:353-358. https://doi.org/10.1007/s10327-009-0181-1

CIMMYT, 2016. Available online: https://repository.cimmyt.org/ xmlui/bitstream/handle/10883/16947/57941.pdf?sequence $=$ $1 \&$ isAllowed $=\mathrm{y}$

CIMMYT, 2017a. Available online: https://www.cimmyt.org/ press_release/australia-funds-worldwide-project-to-restrainwheat-blast-disease/

CIMMYT 2017b.Available online: https://www.cimmyt.org/first-blastresistant-biofortified-wheat-variety-released-in-bangladesh/

CIMMYT 2018.Available online: https://www.cimmyt.org/wheatblast-screening-and-surveillance-training-in-bangladesh/

CIMMYT, 2019. Available online: https://www.cimmyt.org/assessingthe-effectiveness-of-a-wheat-holiday-for-preventing-blastby-examining-alternative-crops-in-the-lower-gangeticplains/

Cong, L., Ran, F.A., Cox, D., Lin, S., Barretto, R., Habib, N., Hsu, P.D., Wu, X., Jiang, W. and Marraffini, L., 2013. Multiplex genome engineering using CRISPR/Cas systems. Science, 339:819-823. https://doi.org/10.1126/science.1231143

Cooke, D.E., Cano, L.M., Raffaele, S., Bain, R.A., Cooke, L.R., Etherington, G.J., Deahl, K.L., Farrer, R.A., Gilroy, E.M. and Goss, E.M., 2012. Genome analyses of an aggressive and invasive lineage of the Irish potato famine pathogen. PLOS Pathogens, 8:1002940. https://doi.org/10.1371/journal.ppat.1002940

Correa Victoria, F.J., Tharreau, D., Martínez Racines, C.P., Valès, M., Prado Patiño, G.A. and Aricapa, M.G., 2001. Combinaciones de genes en arroz para el desarrollo de resistencia durable a Pyricularia grisea en Colombia. Fitopatologia Colombiana, 26:47-54

Couch, B.C. and Kohn, L.M., 2002. A multilocus gene genealogy concordant with host preference indicates segregation of a new species, Magnaporthe oryzae, from M. grisea. Mycologia, 94: 683-693. http://dx.doi.org/10.2307/3761719

Cruz, C. D. and Valent, B., 2017. Wheat blast disease: danger on the move. Tropical Plant Pathology, 42:210-222. https://dx.doi.org/10.1007/s40858-017-0159-z

Cruz, C.D., Peterson, G.L., Bockus, W.W., Kankanala, P., Dubcovsky, J., Jordan, K.W., Akhunov, E., Chumley, F., Baldelomar, F.D. and Valent, B., 2016. The 2NS translocation from Aegilops ventricosa confers resistance to the Triticum pathotype of Magnaporthe oryzae. Crop Science, 56:9901000. https://dx.doi.org/10.2135/cropsci2015.07.0410

Cruz, M. F. A., Prestes, A. M., Maciel, J. L. and Scheeren, P. L., 2010. Partial resistance to blast on common and synthetic wheat genotypes in seedling and in adult plant growth stages. Tropical Plant Pathology, 35: 24-31. http://dx.doi.org/10.1590/S1982-56762010000100004

CSISA, 2014. Available online: https://csisa.org/wp-content/uploads/ sites/2/2014/06/Wheat-Blast-Priority-Brief.pdf

CSISA, 2017. Available online: https://csisa.org/scientists-trained-tofight-wheat-blast-in-south-asia/

Cumagun, C.J.R., Anh, V.L., Vy, T.T.P., Inoue, Y., Asano, H., Hyon, G.S., Chuma, I. and Tosa, Y., 2014. Identification of a hidden resistance gene in tetraploid wheat using laboratory strains of Pyricularia oryzae produced by backcrossing. Phytopathology, 104:634-640. https://doi.org/10.1094/PHYTO-04-13-0106-R

Dean, R.A., Talbot, N.J., Ebbole, D.J., Farman, M.L., Mitchell, T.K., Orbach, M.J., Thon, M., Kulkarni, R., Xu, J.R. and Pan, H., 2005. The genome sequence of the rice blast fungus Magnaporthe grisea. Nature, 434:980. https://dx.doi.org/10.1038/nature03449

Encyclopedia Britannica, 1999. Available online: https://www. britannica.com/science/plant-disease/

Faivre-Rampant, O., Thomas, J., Allègre, M., Morel, J.B., Tharreau, D., Nottéghem, J.L., Lebrun, M.H., Schaffrath, U. and Piffanelli, P. 2008. Characterization of the model system rice-Magnaporthe for the study of non-host resistance in cereals. New Phytologist, 180: 899-910. https://doi.org/10.1111/j.1469-8137.2008.02621.x

FAOSTAT, 2010. Available online: http://faostat.fao.org

Farman, M.L., 2002. Pyricularia grisea isolates causing gray leaf spot on perennial ryegrass (Lolium perenne) in the United States: relationship to $P$. grisea isolates from other host plants. Phytopathology, 92:245-54. https://doi.org/10.1094/PHYTO.2002.92.3.245

Fisher, M.C., Henk, D.A., Briggs, C.J., Brownstein, J.S., Madoff, L.C., McCraw, S.L. and Gurr, S.J., 2012. Emerging fungal threats to animal, plant and ecosystem health. Nature, 484: 186. https://doi.org/10.1038/nature10947

Fukuoka, S. and Okuno, K., 2001. QTL analysis and mapping of pi21, a recessive gene for field resistance to rice blast in Japanese upland rice. Theoretical and Applied Genetics, 103:185190. https://doi.org/10.1007/s001220100611

Garrett, K.A., Dendy, S.P., Frank, E.E., Rouse, M.N. and Travers, S.E., 2006. Climate change effects on plant disease: genomes to ecosystems. Annual Review of Phytopathology, 44:489-509. https://doi.org/10.1146/annurev.phyto.44.070505.143420 
Gasiunas, G., Barrangou, R., Horvath, P. and Siksnys, V., 2012. Cas9crRNA ribonucleoprotein complex mediates specific DNA cleavage for adaptive immunity in bacteria. Proceedings of the National Academy of Sciences, 109:E2579-E2586. https://doi.org/10.1073/pnas.1208507109

Global Rust, 2016. Available online: https://globalrust.org/content/future-wheat-yield

Goulart, A.C.P. and Paiva, F. de A., 1990. Transmissão de Pyricularia oryzae através de sementes de trigo (Triticum aestivum). Fitopatologia Brasileira, 15:359-362. http://dx.doi.org/10.1590/S0100-41582005000200003

Greene, E.A., Codomo, C.A., Taylor, N.E., Henikoff, J.G., Till, B.J., Reynolds, S.H., Enns, L.C., Burtner, C., Johnson, J.E. and Odden, A.R., 2003. Spectrum of chemically induced mutations from a large-scale reverse-genetic screen in Arabidopsis. Genetics, 164:731-740.

Gunnell, P.S. 1992: Aggregate sheath spot. In R.K. Webster and P.S Gunnell (eds).Compendium of Rice Diseases, pp. 23-24. APS Press: St Paul, MN, USA.

Gupta, P.K., 2004. Cereal Genomics: An Overview. In P.K Gupta, R.K. Varshney (eds). Cereal Genomics, pp. 639. Kluwer Academic Press, Dordrecht, the Netherlands.

Hayashi, K., Hashimoto, N., Daigen, M. and Ashikawa, I., 2004 Development of PCR-based SNP markers for rice blast resistance genes at the Piz locus. Theoretical and Applied Genetics, 108:1212-1220. https://doi.org/10.1007/s00122003-1553-0

Hayashi, K., Yoshida, H. and Ashikawa, I., 2006. Development of PCR-based allele-specific and InDel marker sets for nine rice blast resistance genes. Theoretical and Applied Genetics, 113:251-260. https://doi.org/10.1007/s00122006-0290-6

Helliwell, E.E., Wang, Q. and Yang, Y. 2013. Transgenic rice with inducible ethylene production exhibits broad-spectrum disease resistance to the fungal pathogens Magnaporthe oryzae and Rhizoctonia solani. Plant Biotechnology Journal, 11:33-42. https://doi.org/10.1111/pbi.12004

Hovmøller, M.S., Yahyaoui, A.H., Milus, E.A. and Justesen, A.F., 2008. Rapid global spread of two aggressive strains of a wheat rust fungus. Molecular Ecology, 17:3818-3826. https://doi.org/10.1111/j.1365-294X.2008.03886.x

Howard, R.J. and Valent, B., 1996. Breaking and entering: host penetration by the fungal rice blast pathogen Magnaporthe grisea. Annual Review of Microbiology, 50:491-512. https://doi.org/10.1146/annurev.micro.50.1.491

Igarashi, S. 1990.Update on wheat blast (Pyricularia oryzae) in Brazil. Proceedings of the International Conference-Wheat for the Nontraditional Warm Areas, CIMMYT, Mexico, pp. 480483.

Igarashi, S., 1986. Pyricularia em trigo. 1. Ocorrencia de Pyriculariasp. noestado do Parana. Fitopatologia Brasileira, 11:351-352.

Index Mundi, 2016. Available online: https://www.indexmundi.com/agriculture/?commodity=whe at\&graph=production

Islam, M.T., Croll, D., Gladieux, P., Soanes, D.M., Persoons, A., Bhattacharjee, P., Hossain, M.S., Gupta, D.R., Rahman, M.M. and Mahboob, M.G., 2016. Emergence of wheat blast in Bangladesh was caused by a South American lineage of Magnaporthe oryzae. BMC Biology, 14:84. https://doi.org/10.1186/s12915-016-0309-7

Jain, S.M., Brar, D.S. and Ahloowalia, B.S. 2002. Molecular techniques in crop improvement, Kluwer Academic Publishers: Dordrecht, The Netherlands. pp. 772. http://dx.doi.org/10.1007/978-90-481-2967-6

Jinek, M., Chylinski, K., Fonfara, I., Hauer, M., Doudna, J. A. and Charpentier, E., 2012. A programmable dual-RNA-guided DNA endonuclease in adaptive bacterial immunity. Science, 337:816-821. https://doi.org/10.1126/science. 1225829

Joshi, R.K. and Nayak, S., 2010. Gene pyramiding-A broad spectrum technique for developing durable stress resistance in crops. Biotechnology and Molecular Biology Reviews, 5:51-60.

Katiyar-Agarwal, S. and Jin, H., 2010. Role of small RNAs in hostmicrobe interactions. Annual Review of Phytopathology, 48:225-246.https://doi.org/10.1146/annurev-phyto-073009114457

Kato, H., 2001. Rice blast disease. Pesticide Outlook, 12:23-25. http://dx.doi.org/10.1039/B100803J

Kiyosawa, S., 1982. Genetics and epidemiological modeling of breakdown of plant disease resistance. Annual Review of Phytopathology, 20:93-117. https://doi.org/10.1146/annurev.py.20.090182.000521

Klaubauf, S., Tharreau, D., Fournier, E., Groenewald, J.Z., Crous, P.W., De Vries, R.P. and Lebrun, M.H., 2014. Resolving the polyphyletic nature of Pyricularia (Pyriculariaceae). Studies in Mycology, 79:85-120. https://doi.org/10.1016/i.simyco.2014.09.004

Kohli, M.M., Mehta, Y.R., Guzman, E., De Viedma, L. and Cubilla, L.E., 2011. Pyricularia blast-a threat to wheat cultivation. Czech Journal of Genetics and Plant Breeding, 47:130134. https://doi.org/10.17221/3267-CJGPB

Koide, Y., Kawasaki, A., Telebanco-Yanoria, M.J., Hairmansis, A., Nguyet, N.T.M., Bigirimana, J., Fujita, D., Kobayashi, N. and Fukuta, Y., 2010. Development of pyramided lines with two resistance genes, Pish and Pib, for blast disease (Magnaporthe oryzae B. Couch) in rice (Oryza sativa L.). Plant Breeding, 129:670-675. https://doi.org/10.1111/j.1439-0523.2010.01781.x

Kumar, G.R., Sakthivel, K., Sundaram, R.M., Neeraja, C.N., Balachandran, S.M., Rani, N.S., Viraktamath, B.C. and Madhav, M.S., 2010. Allele mining in crops: prospects and potentials. Biotechnology Advance, 28:451-461. https://doi.org/10.1016/j.biotechadv.2010.02.007

Kumar, P., Gupta, V.K., Misra, A.K., Modi, D.R. and Pandey, B.K., 2009. Potential of molecular markers in plant biotechnology. Plant Omics, 2:141.

Leach, J. E., Vera, C. M., Bai, J. and Leung, H., 2001. Pathogen fitness penalty as a predictor of durability of disease resistance genes. Annual Review of Phytopathology, 39:187-224. https://doi.org/10.1146/annurev.phyto.39.1.187

Li, T., Liu, B., Spalding, M.H., Weeks, D.P., Yang, B., 2012. Highefficiency TALEN-based gene editing produces diseaseresistant rice. Nature Biotechnology, 30: 390. https://doi.org/10.1038/nbt.2199

Liu, W., Liu, J., Triplett, L., Leach, J.E and Wang, G.L., 2014. Novel insights into rice innate immunity against bacterial and fungal pathogens. Annual Review of Phytopathology, 52: 213-241. http://dx.doi.org/10.1146/annurev-phyto-102313045926

Maciel, J.L.N., Ceresini, P.C., Castroagudin, V.L., Zala, M., Kema, G.H. and McDonald, B.A. 2014. Population structure and pathotype diversity of the wheat blast pathogen Magnaporthe oryzae 25 years after its emergence in Brazil. Phytopathology, 104:95-107. https://doi.org/10.1094/PHYTO-11-12-0294-R

Malaker, P.K., Barma, N.C., Tiwari, T.P., Collis, W.J., Duveiller, E., Singh, P.K., Joshi, A.K., Singh, R.P., Braun, H.J. and Peterson, G.L., 2016. First report of wheat blast caused by Magnaporthe oryzae pathotype triticum in Bangladesh. Plant Disease, 100:2330-2330. https://dx.doi.org/10.5423\%2FPPJ.RW.09.2016.0179

Malzahn, A., Lowder, L. and Qi, Y. P., 2017. Plant genome editing with TALEN and CRISPR. Cell Bioscience, 7: 21. https://doi.org/10.1186/s13578-017-0148-4

Mammadov, J., Aggarwal, R., Buyyarapu, R. and Kumpatla, S., 2012. SNP markers and their impact on plant breeding. International Journal of Plant Genomics, 2012: 1-11. http://dx.doi.org/10.1155/2012/728398

McCouch, S.R., Nelson, R.J., Tohme, J, Zeigler, R.S. 1994. Mapping blast resistance genes in rice. In: R.S. Zeigler, S.A. Leong, P.S. Teng (eds). Rice blast disease, pp. 167-186. CAB International, Wallingford, England. http://dx.doi.org/ 10.1007/978-1-4020-9500-9

Miyamoto, M., Yano, M. and Hirasawa, H., 2001. Mapping of quantitative trait loci conferring blast field resistance in the Japanese upland rice variety Kahei. Breeding Science, 51:257-261. https://doi.org/10.1270/jsbbs.51.257

Mondal, S., Rutkoski, J.E., Velu, G., Singh, P.K., Crespo-Herrera, L.A., Guzman, C., Bhavani, S., Lan, C., He, X. and Singh, 
R.P., 2016. Harnessing diversity in wheat to enhance grain yield, climate resilience, disease and insect pest resistance and nutrition through conventional and modern breeding approaches. Frontiers in Plant Science, 7:991. https://doi.org/10.3389/fpls.2016.00991

Nga, N. T. T., Hau, V. T. B. and Tosa, Y., 2009. Identification of genes for resistance to a Digitaria isolate of Magnaporthe grisea in common wheat cultivars. Genome, 52:801-809. http://dx.doi.org/10.1094/PHYTO-04-13-0106-R

Ou, S.H. 1985. Rice Diseases. 2nd ed.; Commonwealth Mycological Institute: Kew, Surry, England. pp. 256-380.

Padmanabhan, S.Y., 1973. The great Bengal famine. Annual Review of Phytopathology, 11:11-24. https://doi.org/10.1146/annurev.py.11.090173.000303

Pathogen-genomics, 2016. Available online: http://www.pathogengenomics.org/2/post/2016/04/the-origin-of-the-bangladeshwheat-blast-outbreak-in-2016/

Pennisi, E., 2010. Armed and Dangerous. Science, 327: 804-805. https://doi.org/10.1126/science.327.5967.804

Pereira, J.F., Consoli, L., de Souza Bombonatto, E.A., Bonato, A.L.V. and Maciel, J.L.N., 2014. Development of genomic SSR markers and molecular characterization of Magnaporthe oryzae isolates from wheat in Brazil. Biochemical Genetics, 52:52-70. https://doi.org/10.1007/s10528-013-9627-4

Phillips, R.L. and Vasil, I.K. 2001. DNA-Based Markers in Plants. In R.L. Phillips, I.K. Vasil (eds).DNA-Based Markers in Plants, pp. 497. Kluwer Academic Publishers, Dordrecht, the Netherlands.

Prabhu, A.S., Filippi, M.C. and Castro, N., 1992. Pathogenic variation among isolates of Pyricularia oryzae affecting rice, wheat, and grasses in Brazil. International Journal of Pest Management, 38: 367-371. http://dx.doi.org/10.1080/09670879209371729

Prestes A.M., Arendt P.F., Fernandes J.M.C., Scheeren P.L. 2007. Resistance to Magnaporthe grisea among Brazilian wheat genotypes. In: Buck H.T., Nisi J.E., Salomón N. (eds) Wheat Production in Stressed Environments.Springer, Dordrecht. pp. 119-123. https://doi.org/10.1007/1-40205497-1_16

The Prothom Alo, 2016. Available online: https://en.prothomalo.com/bangladesh/news/102091/Enemy -of-wheat-detected

Sallaud, C., Lorieux, M., Roumen, E., Tharreau, D., Berruyer, R., Svestasrani, P., Garsmeur, O., Ghesquière, A. and Notteghem, J.L., 2003. Identification of five new blast resistance genes in the highly blast-resistant rice variety IR64 using a QTL mapping strategy. Theoretical and Applied Genetics, 106:794-803. https://doi.org/10.1007/s00122-002-1088-9

Semagn, K., Ndjiondjopd, M.N. and Cissoko, M., 2006. Microsatellites and agronomic traits for assessing genetic relationships among 18 New Rice for Africa (NERICA) varieties. African Journal of Biotechnology, 5:800-810. https://doi.org/10.5897/AJB06.140

Silué, D., Notteghem, J. L. and Tharreau, D., 1992. Evidence of a gene-for-gene relationship in the Oryza sativaMagnaporthe grisea pathosystem. Phytopathology, 82:577580. http://dx.doi.org/10.1094/Phyto-82-577

Singh, R.P., Hodson, D.P., Huerta-Espino, J., Jin, Y., Bhavani, S., Njau, P., Herrera-Foessel, S., Singh, P.K., Singh, S. and Govindan, V., 2011. The emergence of $U g 99$ races of the stem rust fungus is a threat to world wheat production. Annual Review of Phytopatholohy, 49:465-481. https://doi.org/10.1146/annurev-phyto-072910-095423

Singh, V.K., Singh, A., Singh, S.P., Ellur, R.K., Choudhary, V., Sarkel, S., Singh, D., Krishnan, S.G., Nagarajan, M. and Vinod, K.K., 2012. Incorporation of blast resistance into "PRR78", an elite Basmati rice restorer line, through marker assisted backcross breeding. Field Crops Research, 128, 8-16. https://doi.org/10.1016/j.fcr.2011.12.003

Skamnioti, P. and Gurr, S.J., 2009. Against the grain: safeguarding rice from rice blast disease. Trends Biotechnology, 27:141-150. https://doi.org/10.1016/j.tibtech.2008.12.002
Song, F. and Goodman, R.M., 2001. Molecular biology of disease resistance in rice. Physiology and Molecular Plant Pathology, 59:1-11. http://dx.doi.org/10.1006/pmpp.2001.0353

Srivastava, D., Shamim, M., Kumar, M., Mishra, A., Pandey, P., Kumar, D., Yadav, P., Siddiqui, M.H. and Singh, K.N., 2017. Current status of conventional and molecular interventions for blast resistance in rice. Rice Science, 24:299-321. https://doi.org/10.1016/i.rsci.2017.08.001

Tabien, R., Li, Z., Paterson, A., Marchetti, M., Stansel, J. and Pinson, S. 2002. Mapping QTLs for field resistance to the rice blast pathogen and evaluating their individual and combined utility in improved varieties. Theoretical and Applied Genetics, 105:313-324. https://doi.org/10.1007/s00122002-0940-2

Takabayashi, N., Tosa, Y., Oh, H. S. and Mayama, S., 2002. A genefor-gene relationship underlying the species-specific parasitism of Avena/Triticum isolates of Magnaporthe grisea on wheat cultivars. Phytopathology, 92:1182-1188. https://doi.org/10.1094/PHYTO.2002.92.11.1182

Talukder, Z. I., Tharreau, D. and Price, A. H., 2004. Quantitative trait loci analysis suggests that partial resistance to rice blast is mostly determined by race-specific interactions. New Phytologist, 162:197-209. https://doi.org/10.1111/j.14698137.2004.01010.x

Tanksley, S.D. and Nelson, J.C., 1996. Advanced backcross QTL analysis: a method for the simultaneous discovery and transfer of valuable QTLs from unadapted germplasm into elite breeding lines. Theoretical and Applied Genetics, 92:191-203. https://doi.org/10.1007/BF00223376

Temnykh, S., DeClerck, G., Lukashova, A., Lipovich, L., Cartinhour, S. and McCouch, S. 2001. Computational and experimental analysis of microsatellites in rice (Oryza sativa L.): frequency, length variation, transposon associations, and genetic marker potential. Genome Research, 11:1441-1452. https://doi.org/10.1101/gr.184001

The Daily Star, 2016a. Available online: https://www.thedailystar.net/ backpage/wheat-blast-threatens-yield-784372/

The Daily Star, 2016b. Available online: https://www.thedailystar.net/backpage/loss-tk-1800cr-yearleast-1235089/

thi Lang, N., Buu, B.C. and Ismail, A., 2008. Molecular mapping and marker-assisted selection for salt tolerance in rice (Oryza sativa L.). Omonrice, 16:50-56.

Tufan, H.A., McGrann, G.R., Magusin, A., Morel, J.B., Miché, L. and Boyd, L.A., 2009. Wheat blast: histopathology and transcriptome reprogramming in response to adapted and non-adapted Magnaporthe isolates. New Phytologist, 184:473-84.https://dx.doi.org/10.1186\%2Fs12915-0160309-7

Urashima A.S. 2010. Blast. In: W.W. Bockus, R.L. Bowden, R.M. Hunger, W.L. Morrill, T.D. Murray, R.W Smiley (eds). Compendium of wheat diseases and pests. pp. 22-23. Saint Paul, MN: American Phytopathological Society.

Urashima, A.S., Hashimoto, Y., Don, L.D., Kusaba, M., Tosa, Y., Nakayashiki, H. and Mayama, S., 1999. Molecular analysis of the wheat blast population in Brazil with a homolog of retrotransposon MGR583. Japanese Journal of Phytopathology, 65:429-436.

Urashima, A.S., Igarashi, S. and Kato, H., 1993. Host range, mating type and fertility of Pyricularia grisea from wheat in Brazil. Plant Disease, 77:1211-1216. https://doi.org/10.1094/PD-77-1211

Urashima, A.S., Martins, T.D., Bueno, C.R.N.C., Favaro, D.B., Arruda, M.A. and Mehta, Y.R., 2004. Triticale and barley: new hosts of Magnaporthe grisea in São Paulo, Brazilrelationship with blast of rice and wheat. In Rice blast: Interaction with rice and control. pp. 251-260. Springer, Dordrecht. https://doi.org/10.1007/978-0-306-48582-4 30

USDA, 2013. Available online: https://www.ars.usda.gov/ ARSUserFiles/00000000/opmp/Wheat\%20Blast\%20Recov ery\%20Plan\%20Final.pdf 
Valent, B., Farrall, L. and Chumley, F.G., 1991. Magnaporthe grisea genes for pathogenicity and virulence identified through a series of backcrosses. Genetics, 127:87-101.

Viedma, L. Q. and Morel, W., 2002. Añublo o Pyricularia del Trigo. Díptico. MAG/DIA/CRIA. Programa de Investigación de Trigo, CRIA, Capitán Miranda, Itapúa.

Vy, T.T.P., Hyon, G.-S., Nga, N.T.T., Inoue, Y., Chuma, I. and Tosa, Y., 2014. Genetic analysis of host-pathogen incompatibility between Lolium isolates of Pyricularia oryzae and wheat. Journal of General Plant Pathology, 80:59-65. https://doi.org/10.1007/s10327-013-0478-y

Wang, F., Wang, C., Liu, P., Lei, C., Hao, W., Gao, Y., Liu, Y.G. and Zhao, K., 2016 Enhanced rice blast resistance by CRISPR/Cas9-targeted mutagenesis of the ERF transcription factor gene OsERF922. PloS One, 11:e0154027. https://doi.org/10.1371/journal.pone.0154027

Wang, G. L., Mackill, D. J., Bonman, J. M., McCouch, S. R., Champoux, M. C. and Nelson, R. J., 1994. RFLP mapping of genes conferring complete and partial resistance to blast in a durably resistant rice cultivar. Genetics, 136:14211434.

Wang, Y., Cheng, X., Shan, Q., Zhang, Y., Liu, J., Gao, C. and Qiu, J.L., 2014. Simultaneous editing of three homoeoalleles in hexaploid bread wheat confers heritable resistance to powdery mildew. Nature Biotechnology, 32:947. https://doi.org/10.1038/nbt.2969

Wang, Z., Jia, Y., Rutger, J.N., and Xia, Y., 2007. Rapid survey for presence of a blast resistance gene $P i$-ta in rice cultivars using the dominant DNA markers derived from portions of the Pi-ta gene. Plant Breeding, 126:36-42. https://doi.org/10.1111/j.1439-0523.2007.01304.x

Wang, S., Asuke, S., Phuong, T.t., Inoue, Y., Chuma, I., Win, J., Kato, K., and Tosa Y., 2018. A new resistance gene in combination with Rmg 8 confers strong resistance against Triticum isolates of Pyricularia oryzae in a common wheat landrace.Phytopathology, 108:1299-1306. https://doi.org/10.1094/PHYTO-12-17-0400-R
Wu, J.L., Fan, Y.Y., Li, D.B., Zheng, K.L., Leung, H. and Zhuang, J.Y., 2005. Genetic control of rice blast resistance in the durably resistant cultivar Gumei 2 against multiple isolates. Theoretical Applied Genetics, 111:50-56. https://doi.org/10.1007/s00122-005-1971-2

Yaegashi, H. and Udagawa, S., 1978. The taxonomical identity of the perfect state of Pyricularia grisea and its allies. Canadian Journal of Botany, 56:180-183. https://doi.org/10.1139/b78-023

Yoshida, K., Saunders, D.G., Mitsuoka, C., Natsume, S., Kosugi, S., Saitoh, H., Inoue, Y., Chuma, I., Tosa, Y. and Cano, L.M., 2016. Host specialization of the blast fungus Magnaporthe oryzae is associated with dynamic gain and loss of genes linked to transposable elements. BMC Genome, 17:370. https://doi.org/10.1186/s12864-016-2690-6

Young, N.D., 1996. QTL mapping and quantitative disease resistance in plants. Annual Review of Phytopathology, 34:479-501. https://doi.org/10.1146/annurev.phyto.34.1.479

Yu, Z.H., Mackill, D.J., Bonman, J.M., McCouch, S.R., Guiderdoni, E., Nottéghem, J.L. and Tanksley, S.D., 1996. Molecular mapping of genes for resistance to rice blast (Pyricularia grisea Sacc.). Theoretical and Applied Genetics, 93:859863. https://doi.org/10.1007/BF00224086

Zenbayashi, K., Ashizawa, T., Tani, T. and Koizumi, S., 2002. Mapping of the QTL (quantitative trait locus) conferring partial resistance to leaf blast in rice cultivar Chubu 32. Theoretical and Applied Genetics, 104:547-552. https://doi.org/10.1007/s00122-001-0779-y

Zhan, S.W., Mayama, S. and Tosa, Y. 2007. Identification of two genes for resistance to Triticum isolates of Magnaporthe oryzae in wheat. Genome, 51:216-221. https://doi.org/10.1139/G07-094

Zhou, J., Xiao, W., Wang, W., Feng, A., Zhu, X., Chen, S. and Chen, Z., 2017. Analysis of a major rice blast resistance gene in the rice restorer line Hanghui 1179. Euphytica, 213:143. https://doi.org/10.1007/s10681-017-1932-2 